\title{
PENERAPAN PEMBELAJARAN BERBASIS DISCOVERY LEARNING MELALUI METODE TALKING STICK UNTUK MENINGKATKAN PEMAHAMAN KONSEP GERAK LURUS
}

Rahma Dani ${ }^{1}$, Nindi Ayu Latifah ${ }^{2}$ dan Septiona Anggela Putri ${ }^{3}$

1,2,3 Program Studi Pendidikan Fisika Universitas Jambi, Jambi, Indonesia

E-mail: rahmadani@unja.ac.id

\section{Info Artikel}

Diterima: 23 Desember 2018

Disetujui: 7 Januari 2019

Dipublikasikan: 15

Desember 2019

\begin{abstract}
Abstrak:
Tujuan penelitian ini untuk mengetahui peningkatan pemahaman konsep gerak lurus melalui pembelajaran berbasis discovery learning melalui metode talking stick. Penelitian ini merupakan jenis penelitian deskriptif eksploratif. Subjek penelitian adalah siswa kelas X MIA 1 SMA Islam Al-Falah Jambi sebanyak 29 siswa. Teknik pengumpulan data melalui tes pemahan konsep, lembar observasi keterampilan peserta didik dan dokumentasi. Teknik analisis data dilakukan secara deskriptif. Peserta didik mengikuti pembelajaran discovery learning melalui metode talking stick pada materi gerak lurus. Peserta didik antusias untuk menjawab pertanyaan, mengemukakan pendapat, dan memberikan tanggapan terhadap jawaban teman. Hasil tes pemahaman konsep diperoleh rata-rata 77,80. Berdasarkan hasil penelitian ini dapat disimpulkan bahwa pembelajaran berbasis discovery learning melalui metode talking stick dapat meningkatkan pemahaman konsep Gerak Lurus.
\end{abstract}

Kata Kunci: Talking Stick, pemahaman konsep, gerak lurus

Abstract:

The purpose of this research is to improve the understanding of straightmotion concepts through discovery learning-based learning through the talking stick method. This research is a kind of exploratory descriptive research. The subject of the study is a student of grade X MIA 1 SMA Islam Al-Falah Jambi as many as 29 students. Data collection techniques through concept-sorting tests, student skills observation sheets and documentation. Data analysis techniques are performed in a descriptive. Learners follow the learning of discovery learning through the talking stick method of straight-motion material. Learners are enthusiastic to answer questions, brainstorm, and respond to friends ' answers. The test result of concept understanding was obtained on average 77.80. Based on the results of the study it can be concluded that discovery learning based learning through the talking stick method can improve the understanding of the straight motion concept.

Keyword: Talking Stick, conceptual understanding, linier motion 


\section{Pendahuluan}

Pendidikan merupakan suatu proses interaksi manusia dengan lingkungannya yang berlangsung secara sadar dan terencana dalam rangka mengembangkan segala potensinya (Ahmadi,2014). Pendidikan tidak luput dari belajar dan pembelajaran.

Belajar adalah suatu proses usaha yang dilakukan seseorang untuk memperoleh perubahan tingkah laku yang baru secara keseluruhan, sebagai hasil pengalamannya sendiri dalam interaksi dengan lingkungannya (Slameto, 2003). Sedangkan menurut Halim (2012) belajar adalah suatu proses. Artinya kegiatan belajar terjadi secara dinamis dan berkelanjutan, yang menyebabkan terjadinya perubahan dalam diri anak.

Salah satu pembelajaran yang penting di sekolah adalah pembelajaran fisika.

Fisika merupakan salah satu cabang IPA yang bertujuan mempelajari dan menganalisis gejala atau proses alam dan sifat zat serta penerapannya. Fisika tidak hanya berupa fakta, hukum, rumus, dan hitungan belaka, tetapi juga merupakan pelajaran yang mengkaji tentang dunia dan kehidupan (Rahayu,2015).

Pembelajaran Fisika di sekolah merupakan hal yang penting dalam keterlibatanya mencerdaskan kehidupan bangsa, karena dengan adanya pembelajaran Fisika peserta didik dilatih untuk dapat memahami berbagai hal dan fenomena yang terjadi di alam dan mengetahui keterkaitannya dengan ilmu yang ada. Dengan adanya usaha pendidikan, keberhasilan di dalam pendidikan senantiasa akan terbangun, secara otomatis dengan adanya keberhasilan pendidikan maka akan mendukung pencapaian target mencerdaskan kehidupan bangsa, agar senantiasa siap bersaing di era globalisasi yang syarat dengan kemajuan ilmu pengetahuan dan teknologi.

Fisika merupakan ilmu fundamental yang menjadi dasar perkembangan ilmu pengetahuan dan teknologi. Mengingat begitu pentingnya peranan ilmu fisika, sudah semestinya fisika dipahami dengan baik oleh siswa. Upaya siswa dalam mempelajari fisika sering menemui hambatan-hambatan. Fisika biasanya dianggap sebagai pelajaran yang sulit dipahami. Hal itu mungkin menyebabkan hasil belajar siswa menjadi kurang baik (Pujianto,2013).
Hakikat fisika ilmu pengetahuan yang mempelajari gejala yang dilakukan dengan metode ilmiah yang dibangun dari sikap ilmiah yang akan menghasilkan produk ilmiah berupa konsep, prinsip dan teori (Trianto, 2011:59). Tetapi dalam kenyataannya, siswa kurang tertarik pada pelajaran fisika, sehingga mempengaruhi hasil belajar yang mereka capai (Lubis, 2012).

Salah satu studi internasional mengenai kemampuan kognitif peserta didik yaitu TIMSS (Trends in Mathematics and Science Study) yang diadakan oleh IEA (International Association for the Evaluation of Educational Achievement). Hasil TIMSS 2011 pada bidang Fisika menunjukkan Indonesia memperoleh nilai 397 dimana nilai ini berada di bawah nilai rata-rata internasional yaitu 500. Berdasarkan data prosentase rata-rata jawaban benar untuk konten sains dan domain kognitif (Martin, dkk, dalam Rofiah, dkk, 2013). Data tersebut menjelaskan bahwa kemampuan kognitif peserta didik di Indonesia dalam pembelajaran Fisika tergolong rendah.

Bayak faktor yang dapat menyebabkan rendahnya taraf pemahaman peserta didik dalam mempelajari ilmu fisika, diantaranya yaitu kurangnya minat dan motivasi peserta didik dalam memahami materi pemebelajaran, adanya pemahaman konsep yang keliru oleh peserta didik, cara penyampaian materi yang kurang menarik, cara belajar peserta didik, serta media yang digunakan dalam proses pembelajaran yang kurang menarik. Selain itu cara belajar dengan pola menghafal dan tuntutan ketepatan dalam menghitung juga berdampak terhadap persepsi peserta didik tentang mata pelajaran Fisika.

Di dalam pembelajaran, peserta didik didorong untuk menemukan sendiri dan mentransformasikan informasi kompleks, mengecek informasi baru dengan yang sudah ada dalam ingatannya, dan melakukan pengembangan menjadi informasi atau kemampuan yang sesuai dengan lingkungan dan zaman. Konteks ini sangat sesuai dengan salah satu model pembelajaran yang menggunakan pendekatan saintifik, yaitu discovery learning (Perdana,2017).

Model discovery learning (DL) adalah salah satu model pembelajaran yang mendorong siswa untuk mengajukan pertanyaan dan menarik kesimpulan dari prinsip-prinsip umum 
praktis contoh pengalaman. Dalam model DL menggunakan pendekatan saintifik, yaitu siswa melaksanakan sendiri tiap langkahnya dengan bimbingan guru (Hosnan,2014).

Penerapan model DL sesuai dengan beberapa materi pembelajaran IPA fisika, salah satunya pada materi gerak lurus. Siswa akan menemukan sendiri bagaimana konsep gerak lurus melalui rangkaian eksperimen atau percobaan. Siswa akan menemukan sendiri bagaimana konsep dan prinsip dari submateri kedudukan dan perpindahan, kecepatan dan kelajuan, gerak lurus beraturan serta gerak lurus berubah beraturan. Siswa juga diharapkan mengikuti langkahlangkah discovery learning yang sangat berkesesuaian dengan keterampilan proses sains (Sati, 2017).

Berdasarkan pengalaman mengajar yang dilakukan oleh penulis di kelas X MIA 1 SMA Islam Al-Falah Jambi Tahun ajaran 2018-2019 dan dengan melakukan telaah hasil evaluasi pembelajaran fisika, diperoleh informasi bahwa peserta didik mengalami kendala dalam pemahaman konsep pada proses pembelajaran Fisika. Pemahaman merupakan suatu pengetahuan atau perspektif seseorang dalam melihat suatu masalah. Seseorang dikatakan mampu memahami jika dia dapat menarik makna dari suatu pesan-pesan atau petunjukpetunjuk dalam soal-soal yang dihadapinya (Suwanto,2014), sedangkan menurut Sudjana (2011), pemahaman merupakan tingkat hasil belajar yang lebih tinggi daripada pengetahuan yang diperoleh, perlu adanya mengenal atau mengetahui untuk dapat memahami

Kebanyakan peserta didik belum mampu memahami permasalahan di bidang Fisika dan lemah dalam mengaplikasikan konsep Fisika ke dalam pemecahan masalah berbentuk soal. Selain itu, peserta didik juga berasumsi bahwa pembelajaran fisika adalah pembelajaran ynag sulit dan kurang menarik.

Pembelajaran fisika di kelas X MIA 1 pada dasarnya telah menerapkan kurikulum pendidikan terbaru (Kurikulum 2013) yang menuntut peserta didik untuk aktif di dalam pembelajaran. Peserta didik ditintut untuk memahami konsep pembelajaran secara mandiri, namun kondisi praktek pengajaran masih berfokus pada guru. Oleh karena itu perlu diadakan evaluasi proses pembelajaran di kelas X MIA 1 SMA Islam Al-Falah Jambi tahun ajaran 2018-2019, serta upaya dalam rangka meningkatkan pemahaman konsep peserta didik terkait materi yang diajarkan, agar peserta didik tidak terus berada di dalam kesalahpahaman konsep yang dialami.

Dengan adanya upaya penyelesaian atau penanganan masalah, guru dapat menentukan upaya penanganan masalah yang tepat untuk dilakukan dalam rangka penyelesaian masalah dari sisi peserta didik maupun guru. Peserta didik juga dapat lebih memahami maksud dari materi pembelajaran yang diajarkan oleh guru sehingga tidak terjadi miskonsepsi. Selain itu pihak sekolah dapat mengetahui bagaimana kondisi kelengkapan fasilitas belajar yang dirasa mendukung proses pembelajaran. Tujuan dari penelitian ini yaitu untuk meningkatkan pemahaman konsep peserta didik kelas X MIA 1 SMA Islam Al-Falah Jambi terhadap materi pembelajaran gerak lurus melalui pembelajaran berbasis discovery learning dengan melalui metode talking stick.

\section{Metode Penelitian}

Jenis Penelitian

Penelitian ini merupakan jenis penelitian deskriptif eksploratif.

Waktu dan Tempat Penelitian

Penelitian ini dilakukan pada bulan September-Oktober 2018 padaa peserta didik kelas X MIA 1 SMA Islam Al-Falah Jambi.

Subjek Penelitian

Subjek penelitian adalah siswa kelas $\mathrm{X}$ MIA 1 SMA Islam Al-Falah Jambi yang berjumlah 29 orang.

\section{Prosedur}

Data penelitian diperoleh dari tes pemahaman konsep dan pengisian lembar observasi keterampilan dan keaktifan siswa di kelas. Tes pemahaman konsep yang diberikan berupa kumpulan pertanyaan yang berkaitan dengan konsep materi yang diajarkan. Tes pemahaman konsep ini dilakukan dengan menggunakan model pembelajaran talking stick. Sedangkan lembar observasiketerampilan dan keaktifan siswa digunakan untuk mengetahui keterlaksanaan pembelajaran dengan menggunakan melalui metode talking stick dalam pembelajaran berbasis discovery learning. 
Teknik Analisis Data

Instumen penelitian berupa tes pemahaman konsep dan lembar observasi untu mengukur keterampilan dan keaktifan siswa akan menghasilkan data penelitian. Data yang diperoleh berupa data kualitatif dan kuantitatif. Data-data tersebut akan dianalisis secara deskriptif.

\section{Hasil Penelitian dan Pembahasan}

Penelitian terhadap penerapan pembelajaran berbasis discovery learning (melalui metode talking stick) untuk meningkatkan pemahaman konsep gerak lurus pada peserta didik menggunakan instrumen pengumpul data berupa tes pemahaman konsep dan lembar observasi untu mengukur keterampilan dan keaktifan siswa. Dua instrumen tersebut juga dilengkapi dengan dokumentasi kegiatan. Instrumen tersebut di terapkan terhadap 29 siswa kelas X MIA 1 SMA Islam Al-Falah Jambi. Penelitian ini dilakukan berdasarkan pengamatan dan studi literature terhadap hasil akademik pemahaman konsep peserta didik pada materi pembelajaran sebelumnya. Pembelajaran sebelumnya menerapkan pembelajaran berpusat pada guru, ternyata pemahaman konsep dan keaktifan peserta didik terhadap materi pembelajaran masih kurang. Hal ini dapat dilihat pada Tabel 1.

Berdasarkan permasalahan tersebut peneliti melakukan upaya penyelesaian masalah dengan menggunakan model pembelajaran discovery learning (melalui metode talking stick). Model pembelajaran berbasis discovery learningyang didukung dengan model pembelajaran talking stickdiharapkan mampu membantu peserta didik untuk meningkatkan kemampuan berpikir kritis, karena melalui sintak dalam model tersebut peserta didik dituntut dapat menemukan konsep materi pembelajaran secara mandiri, artinya peran guru di dalam pembelajaran hanya sebatas fasilitator dan pemberi arahan agar peserta didik dapat menemukan konsep pembelajaran secara aktif melalui pemikiran mereka mengenai fenomena-fenomena yang disajikan oleh peneliti (guru).

Model pembelajaran discovery learning dipilih untuk diterapkan diawal pembelajaran, karena hasil akhir dari model pembelajaran ini adalah tercapainya pemahaman konsep peserta didik mengenai materi pembelajaran. Adapun tahapan model pembelajaran discovery learning yaitu stimulasi, identifikasi masalah, mengumpulkan data dan informasi, mengolah data dan informs, verifikasi, dan kesimpulan.

Sedangkan model pembelajaran talking stick, dipilih sebagai cara peneliti untuk memverifikasi pemaham konsep peserta didik melalui kegiatan bermain tongkat. Hasil penerapan pembelajaran berbasis discovery learning dengan melalui metode talking stick dapat dilihat pada Tabel 2 .

Dengan penerapan model pembelajaran discovery learning, penulis mendapatkan hasil bahwa peserta didik lebih tertarik dan lebih aktif di dalam pembelajaran. Peserta didik lebih antusias untuk menjawab beberapa permasalah mengenai fenomena yang berkaitan dengan materi pembelajaran dibandingkan dengan model pembelajaran yang masih berpusat pada guru. Fenomena dan permasalahan yang digunakan oleh penulis untuk memberikan stimulus pemahaman konsep kepada peserta didik disajikan dengan menggunakan media power point, sehingga peserta didik tidak bosan dan lebih tertarik untuk memperhatikan penyampaian materi pembelajaran, mengingat bahwa pembelajaran fisika di kelas X MIA 1 berlangsung pada siang hari.

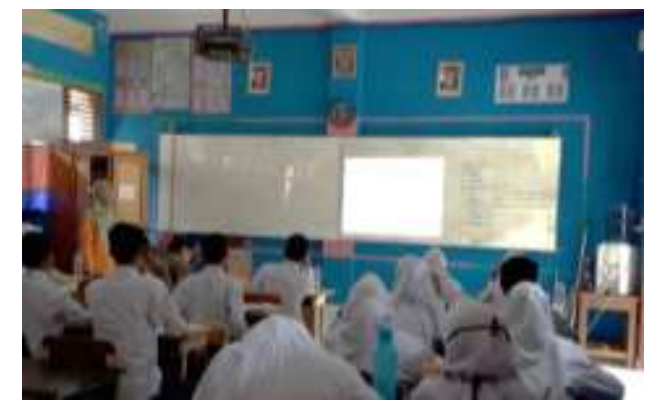

Gambar 1. Peneliti menggunakan media power point

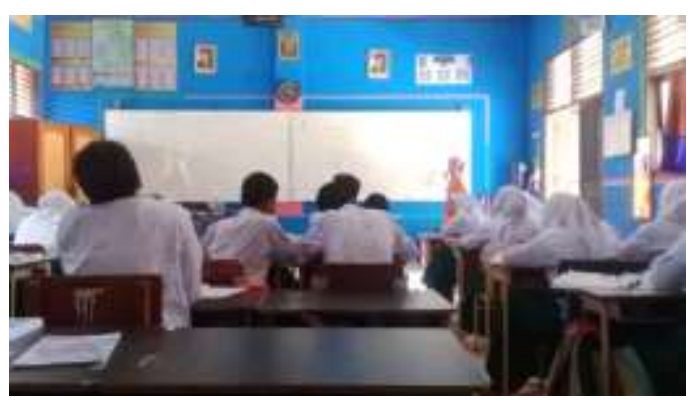

Gambar 2. Kegiatan Pembelajaran berbasis discovery learning 
Setelah melakukan pembelajaran berbasisdiscovery learning, penulis melakukan verifiksi pemahaman konsep peserta didik dengan menggunakan metode permainan model pembelajaran talking stick. Kegiatan ini dilakukan dengan menggunakan tongkat dan musik, peserta didik akan menggilir tongkat secara estafet, saat musik berhenti peserta didik yang memegang tongkat harus menjawab pertanyaan penulis (guru) yang berkaitan dengan konsep dari materi yang telah dipelajari. Peserta didik yang berhasi menjawab pertanyaan akan diberikan hadiah sedangkan peserta didik yang tidak bisa menjawab akan diberi hukuman.

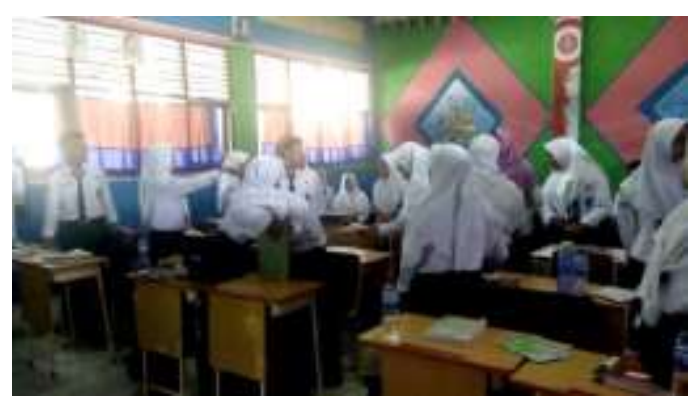

Gambar 3 Pelaksanaan pembelajaran dengan melalui metode talking stick

Berdasarkan kegiatan yang telah dilakukandiperoleh hasil bahwa mayoritas siswa lebih tertarik dan lebih memahami konsep pembelajaran (materi pembelajaran gerak lurus). Meningkatnya pemahaman konsep peserta didik dapat dilihat dari kemampuan peserta didik untuk menjawab tes pemahaman konsep yang diberikan oleh penulis (guru). Lebih dari $70 \%$ pertanyaan dapat dijawab oleh seluruh peserta didik melalui metode pembelajaran talking stick.

Tabel 1.Keaktifan Siswa Sebelum Pembelajaran Berbasis Discovery Learning (Melalui metode talking stick)

\begin{tabular}{llc}
\hline No & \multicolumn{1}{c}{ Kriteria Aspek } & $\begin{array}{c}\text { Rata-Rata } \\
\text { Nilai }\end{array}$ \\
\hline $\mathbf{1}$ & Mengemukakan pendapat & 71.20 \\
$\mathbf{2}$ & Menjawab pertanyaan & 69.82 \\
$\mathbf{3}$ & Menjelaskan tugas & 69.65 \\
$\mathbf{4}$ & Memberi tanggapan & 69.65 \\
\hline
\end{tabular}

Tabel 2. Hasil Observasi Keterampilan Dan Keaktifan Siswa

\begin{tabular}{llc}
\hline No & \multicolumn{1}{c}{ Kriteria Aspek } & $\begin{array}{c}\text { Rata-Rata } \\
\text { Nilai }\end{array}$ \\
\hline $\mathbf{1}$ & Mengemukakan pendapat & 68.03 \\
$\mathbf{2}$ & Menjawab pertanyaan & 74.10 \\
$\mathbf{3}$ & Menjelaskan tugas & 73.57 \\
$\mathbf{4}$ & Memberi tanggapan & 75.00 \\
\hline
\end{tabular}

Hasil penelitian dari penerapan model pembelajaran talking stick di kelas X MIA 1 SMA Islam Al-Falah Jambi menunjukkan bahwa model pembelajaran tersebut telah mampu meningkatkan pemahaman konsep peserta didik pada materi pembelajaran Gerak Luru. Penggunaan model pembelajaran yang menarik merupakan hal penting yang haurs dipertimbangkan dalam kegiatan pembelajaran bagi pendidik dan peserta didik. Pemilihan dan penerapan model pembelajaran yang tepat dapat mempermudah penyampaikan materi pembelajaran sehingga proses pembelajaran akan lebih efektif dan hasil belajar dapat dicapai secara maksimal. Hal ini sesuai dengan penelitian yang dilakukan oleh Fatimah, dkk (2016) yang berjudul: "Pengaruh Model Pembelajaran Tipe Talking Stick unntuk Meningkatkan Hasil Belajar Fisika Siswa SMA Negeri 1 Jiwan Tahun Ajaran 2015/2016". Jurnal. Surakarta: Pascasarjana Ilmu Fisika, Universitas Sebelas Maret. Hasi penelitian menunjukkan bahwa melalui pembelajaran kooperatif tipe talking stick terbukti dapat meningkatkan hasil belajar fisika siswa kelas X IPA 1 SMAN 1 Jiwan. Hal ini terlihat pada hasil penelitian yang menunjukkan bahwa terjadi peningkatan nilai rata-rata kelas $(61,25$ menjadi 77,80).

Penelitian terdahulu yang dilakukan oleh Agustina, dkk (2015) yang berjudul: "Meningkatkan Kemampuan Metakognitif Dan Aktivitas Belajar Melalui Penerapan Model Pembelajaran Talking Stick Di SMPN 1 Balerejo Tahun Pelajaran 2014/2015”. Jurnal. Madiun: Pendidikan Biologi, FMIPA, IKIP, PGRI Madiun. Hasil penelitian menunjukkan bahwa pengetahuan metakognitif siswa pada mengalami peningkatan menjadi $84,74 \%$ setelah sebelumnya sebesar $44,22 \%$. Setelah mengukuti pembelajaran siswa lebih bisa mengkonstruksi hasil belajarnya sendiri, sehingga siswa lebih bisa mengemukakan apa yang belum siswa mengerti pada materi, siswa 
lebih bisa menjabarkan dan menyebutkan apa yang belum siswa mengerti dan pahami dalam materi, hal ini menunjukkan bahwa adanya peningkatan dalam pemahaman materi pelajaran.

\section{Simpulan dan Saran}

Simpulan

Berdasarkan data hasil penelitian dan analisis deskriptif yang telah dilakukan, dapat dinyatakan bahwa penerapan penerapan pembelajaran berbasis discovery learning untuk meningkatkan pemahaman konsep gerak lurus melalui melalui metode talking stick kelas $\mathrm{X}$ MIA 1 SMA Islam Al-Falah Jambi telah berhasil dilakukan. Dengan berhasilnya penelitian ini dapat disumpulkan bahwa pemahaman konsep pesererta didik akan meteri pembelajan fisika dapat ditingkatkan apabila guru dapat memilih metode mengajar yang cocok dan menarik bagi peserta didik. Keberhasilan penelitian dapat dilihat dari instrument pengumpul data yang digunakan. Dengan instrument tersebut didapatkan bahwa lebih dari $70 \%$ pertanyaan (untuk tes pemehaman konsep) dapat dijawab oleh peserta didik. Selain itu keaktifan peserta didik di kelas juga meningkat, hal ini terlihat dari antusiasme peserta didik untuk menjawab pertanyaan, mengemukakan pendapat, dan memberikan tanggapan terhadap jawaban teman.

Saran

Untuk penelitian selanjutnya dapat dilakukan penelitian serupa untuk materi pembelajaran yang sesuai dengan model pembelajaran yang akan digunakan atau dengan menvariasikan model pembelajaran.

\section{Daftar Pustaka}

Ahmadi, Rulam. 2014. Pengantar Pendidikan.Jakarta: Ar-ruzz Media

Agustina, dkk. 2015. Meningkatkan Kemampuan Metakognitif dan ktifitas Belajar Melalui Penerapan Model Pembelajaran Talking Stick di SMPN 1 Balerejo Tahun Pelajaran 2014/2015. Florea, Volume 2 No.2.
Fatimah. 2016. Pengaruh Model Pembelajaran Tipe Talking Stick untuk Meningkatkan Hasil Belajar Fisika Siswa SMA Negeri 1 Jiwan Tahun Ajaran 2015/2016. Prosiding Seminar Nasional Fisika dan Aplikasinya (SNFA), ISSN: 2548-8325.

Halim, A. 2012. Pengaruh Strategi Pembelajaran dan Gaya Belajar terhadap Hasil Belajar Fisika Siswa Smpn 2 Secanggang Kabupaten Langkat. Jurnal Tabularasa PPS Unimed, 9(2): 141-158.

Hosnan, M. 2014. Pendekatan Saintifik dan Kontekstual Dalam Pembelajaran Abad 21. Bogor: Ghalia Indonesia

Lubis, Asneli. 2012. "Pengaruh Model Pembelajaran Kooperatif Tipe STAD Terhadap Hasil Belajar Fisika Siswa Pada Materi Pokok Gerak Lurus di Kelas X SMA Swasta UISU Medan". Jurnal Pendidikan Fisika. Vol.1 (1): 612

. Perdana, A., Siswoyo, S., \& Sunaryo, S. 2017. Pengembangan Lembar Kerja Siswa Berbasis Discovery Learning Berbantuan Phet Interactive Simulations Pada Materi Hukum Newton. Wahana Pendidikan Fisika, 2(1)

Pujianto, Agus. 2013. Analisis Konsepsi Siswa pada Konsep Kinematika Gerak Lurus. 1, (1), 3-6

Rahayu, Arista, dkk. 2015. Pengembangan Media Pembelajaran Hukum Newton Menggunakan Fotonovela Berbasis Kearifan Lokal. Jurnal Fisika, Vol. 4. ISSN 2339-0654.

Rofiah, dkk. 2013. Penyusunan Instrumen Tes Kemampuan Berpikir Tingkat Tinggi Fisika Pada Siswa SMP. Jurnal Pendidikan Fisika, ISSN: 2338 0691, Vol.1 No.2, hal 17.

Sati, Dina Laras. 2017. Penerapan Model Discovery Learning untuk Meningkatkan Hasil Belajar Kognitif 
dan Keterampilan Proses Sains Di Kelas VII.B SMPN 10 Kota Bengkulu. Jurnal Pembelajaran Fisika, Vol. 1. NO. 1.

Slameto. 2003. Belajar dan Faktor-Faktor Yang Mempengaruhinya. Jakarta: Rineka Cipta.

Sudjana, N. 2011. Penilaian Proses Hasil Belajar Mengajar. Bandung: Remaja Rosdakarya
Suwanto, A. 2014. Pengembangan Bahan Ajar Tematik (Tinjauan Teoritis dan Praktis). Jakarta: Kencana.

Trianto. 2011. Model Pembelajaran Terpadu: Konsep, Strategi, dan Implementasinya dalam Kurikulum Tingkat Satuan Pendidikan (KTSP). Jakarta : Bumi Aksara. 